\title{
PENGARUH VARIETAS DAN KEPADATAN TANAM TERHADAP PERTUMBUHAN DAN HASIL PADI (Oryza sativa L.) PADA LAHAN SAWAH DI ANTURAN
}

\author{
Putu Sri Wahyuni $^{1}$, Nyoman Srilaba ${ }^{1}$, Emy Alberthina Rumtily ${ }^{2}$ \\ email: sri.wahyuni@unipas.ac.id \\ ${ }^{1}$ Staf edukatif Fakultas Pertanian Universitas Panji Sakti Singaraja \\ ${ }^{2}$ Alumni Fakultas Pertanian Universitas Panji Sakti Singaraja
}

\begin{abstract}
The purpose of this study was to determine the effect of several rice paddy varieties, the effect of planting density and their interaction on the growth and yield of rice. This research was conducted in September - December 2011 in the rice fields of Subak Anturan, Anturan Village, Buleleng Subdistrict, at an altitude of $\pm 3 m$ above sea level. This study used a split plot desgn based on a randomized block design (RBD) consisting of two factors. The main factor is the variety factor which consists of three factors, namely the Ciherang variety, the Inpari 3 variety and the Inpari 10 variety. An additional factor is the legowo planting factor consisting of four levels, namely how to plant a $20 \times 20 \mathrm{~cm}$ tile population of 250,000 per hectare, how to grow legowo $2: 1$ population 166,660 per hectare, how to plant legowo 2: 1 population 250,000 per hectare, and how to plant legowo 2: 1 population 333,333 per hectare .. Both of these factors were combined so that there were 12 combination treatments. Each combination treatment was repeated three times, so there were 36 treatment units. The effect of the types of rice varieties showed that the Ciherang variety tended to yield grain content of 14\% per hectare heavier, ie 6.81 tons. In Inpari 10 and Inpari 3 varieties give yields of grain moisture content of $14 \%$ per hectare, which is 6.16 tons and 6.17 tons or lower $9.54 \%$ and $6.17 \%$ compared to the results in the Ciherang variety. Jajar legowo 2: 1 planting with a population of 333,333 clumps per hectare was evidently yielding grain content of $14 \%$ per hectare which was heavier, ie 7.11 tons, or $7.24 \%$ more weight compared to the yield of $14 \%$ moisture content per hectare achieved in a population of 250,000 clumps per hectare of planting trees. The interaction between the types of rice varieties and planting density had no significant effect on all observed variables.

Keywords: variety, density, rice fields, growth, and yield.
\end{abstract}

Abstrak: Tujuan dari penelitian ini adalah untuk mengetahui pengaruh beberapa varietas padi sawah, pengaruh kepadatan tanam dan interaksinya terhadap pertumbuhan dan hasil produksi padi. Penelitian ini telah dilaksanakan pada bulan September - Desember 2011 di lahan sawah Subak Anturan, Desa Anturan, Kecamatan Buleleng pada ketinggian tempat $\pm 3 \mathrm{~m}$ dari atas permukaan laut. Penelitian ini menggunakan rancangan petak terpisah (split plot desgn) dengan dasar rancangan acak kelompok (RAK) yang terdiri dari dua faktor. Faktor utama adalah faktor varietas yang terdiri dari tiga faktor yaitu varietas Ciherang, varietas Inpari 3 dan varietas Inpari 10. Faktor tambahan adalah faktor cara tanam legowo terdiri dari empat taraf yaitu cara tanam tegel $20 \times 20 \mathrm{~cm}$ populasi 250.000 per hektar, cara tanam legowo 2:1 populasi 166.660 per hektar, cara tanam legowo 2:1 populasi 250.000 per hektar, dan cara tanam legowo 2:1 populasi 333.333 per hektar.. Kedua faktor ini dikombinasikan sehingga terdapat 12 perlakuan kombinasi. Masing-masing perlakuan kombinasi diulang tiga kali, sehingga berjumlah 36 unit perlakuan. Pengaruh jenis varietas padi menunjukkan bahwa Varietas Ciherang cenderung memberikan hasil gabah kadar air 14\% per hektar lebih berat, yaitu 6,81 ton. Pada varietas Inpari 10 dan Inpari 3 memberikan hasil gabah kadar air 14\% per hektar, yaitu 6,16 ton dan 6,17 ton atau lebih rendah 9,54\% dan 6,17\% dibandingkan dengan hasil pada Varietas Ciherang. Tanam jajar legowo 2:1 dengan populasi 333.333 rumpun per hektar nyata memberikan hasil gabah kadar air $14 \%$ per hektar yang lebih berat, yaitu 7,11 ton, atau nyata lebih berat 7,24\% dibandingkan dengan hasil gabah kadar air $14 \%$ per hektar yang dicapai pada populasi 250.000 rumpun per hektar tanam tegel. Interaksi antara jenis vatietas padi dan kepadatan tanam berpengaruh tidak nyata terhadap semua variabel yang diamati.

Kata kunci: varietas, kepadatan, sawah, pertumbuhan, dan hasil.

\section{PENDAHULUAN}

Berbagai upaya untuk

meningkatkan produktivitas padi secara berkelanjutan selama beberapa tahun terakhir ini menghadapi masalah terutama dengan rendahnya efisiensi usahatani. Untuk itu diperlukan suatu terobosan teknologi yang mampu meningkatkan efisiensi usahatani padi. Salah satu alternatif teknologi adalah melalui penerapan sistem tanam legowo-2:1 yang telah dikaji. Hasil pengkajian menunjukkan bahwa dengan tersedianya ruang luas yang memanjang ke satu arah, maka legowo 2:1 dibandingkan dengan sistem tegel, memberikan beberapa keuntungan diantaranya: peningkatan 
produksi secara nyata dan konsisten melalui peningkatan kepadatan tanaman dan efek tanaman pinggir, memudahkan pemeliharaan, serta menekan serangan hama dan penyakit, atau kemungkinan terjadinya keracunan zat besi (Anonim. 2011a).

Untuk itu diperlukan terobosan teknologi antara lain sistem tanam legowo2:1. Hasil pengkajian menunjukkan bahwa dengan tersedianya ruang luas yang memanjang ke satu arah, maka legowo 2:1 dibandingkan dengan sistem tegel, memberikan beberapa keuntungan diantaranya: peningkatan produksi secara nyata dan konsisten melalui peningkatan kepadatan tanaman dan efek tanaman pinggir, memudahkan pemeliharaan, serta menekan serangan hama dan penyakit, atau kemungkinan terjadinya keracunan zat besi.

Sistem Tanam Jajar Legowo 2 : 1 (40 $\mathrm{cm} \times(20 \mathrm{~cm} \times 10 \mathrm{~cm})$ adalah salah satu cara tanam pindah sawah yang memberikan ruang (barisan yang tidak ditanami) pada setiap dua barisan tanam, tetapi jarak tanam dalam barisan lebih rapat yaitu $10 \mathrm{~cm}$, sehingga kepadatan bisa lebih dari 300.000 rumpun per hektar. Pada prinsipnya sistem tanam jajar legowo adalah meningkatkan kepadatan dengan cara mengatur jarak tanam. Selain itu sistem tanam tersebut juga memanipulasi lokasi tanaman sehingga seolah-olah tanaman padi dibuat menjadi taping (tanaman pinggir) lebih banyak. Teknologi legowo merupakan rekayasa teknik tanam dengan mengatur jarak tanam antar rumpun dan antar barisan sehingga terjadi pemadatan rumpun padi dalam barisan dan memperlebar jarak antar barisan sehingga seolah-olah rumpun padi berada di barisan pinggir dari pertanaman yang memperoleh manfaat sebagai tanaman pinggir (border effect). Pada tanam tegel menggunakan jarak tanam $20 \times 20 \mathrm{~cm}$, maka pada teknologi jajar legowo 2:1, dirubah menjadi $20 \times 10 \times 40 \mathrm{~cm}$, sehingga akan diperoleh kepadatan sebanyak 33 rumpun $/ \mathrm{m}^{2}$ atau 330.000/ha. Maka dengan penggunaan sistem jajar legowo 2 : 1 mampu meningkatkan kepadatan tanaman sebanyak $80.000 \quad$ rumpun/ha (Anonim.2012).

Varietas unggul padi merupakan salah satu komponen teknologi yang berperan sangat dominan dalam meningkatkan produktivitas dan produksi beras dalam negeri. Varietas unggul pada umumnya memiliki sifat-sifat yang menonjol dalam hal potensi hasil tinggi, tahan terhadap organism pengganggu tertentu, dan memiliki keunggulan pada ekolokasi tertentu serta mempunyai sifat-sifat agronomis penting lainnya. Dengan menggunakan varietas unggul tahan hama dan penyakit adalah cara paling murah menekan pengganggu tanaman. Tanpa adanya kekhawatiran akan dampak negatif terhadap lingkungan. Melalui perbaikan cara tanam padi dengan sitem jajar legowo diharapkan selain dapat meningkatkan produksi, pengendalian organisme pengganggu dan pemupukan mudah dilakukan (Anonim. 2011b).

\section{BAHAN DAN METODE}

Penelitian ini telah dilaksanakan pada bulan September - Desember 2011di lahan sawah Subak Anturan, Desa Anturan, Kecamatan Buleleng pada ketinggian tempat $\pm 3 \mathrm{~m}$ dari atas permukaan laut.

Penelitian ini menggunakan rancangan petak terpisah (split plot design) dengan dasar rancangan acak kelompok (RAK) yang terdiri dari dua faktor. Faktor utama adalah faktor varietas yang terdiri dari tiga taraf dan faktor tambahan adalah faktor cara tanam legowo terdiri dari empat taraf. Dari kedua faktor ini kemudian dikombinasikan sehingga terdapat 12 perlakuan kombinasi. Masingmasing perlakuan kombinasi diulang tiga kali, sehingga berjumlah 36 unit perlakuan. Perlakuan varietas padi (V) terdiri dari tiga taraf yaitu varietas Ciherang $(\mathrm{Ch})$, varietas Inpari $3\left(\mathrm{I}_{3}\right)$, dan varietas Inpari $10\left(\mathrm{I}_{10}\right)$. Faktor Cara tanam legowo 2:1 terdiri dari empat taraf yaitu 
cara tanam tegel $20 \times 20 \mathrm{~cm}$ kepadatan 250.000 per hektar (To), cara tanam legowo 2:1 kepadatan 166.660 per hektar (Lk), cara tanam legowo 2:1 kepadatan 250.000 per hektar (Lo), cara tanam legowo 2:1 kepadatan 333.333 per hektar (Lp). Data hasil percobaan dianalisa secara statistik dengan menggunakan analisa varian dan analisis lanjutan yaitu membandingkan nilai rata-rata perlakuan dengan metode uji BNT (Hanafiah, 2000).

\section{HASIL DAN PEMBAHASAN \\ Hasil \\ Tinggi tanaman}

Pengaruh jenis varietas padi terhadap pertumbuhan tinggi tanaman padi masih menunjukkan pertambahan tinggi tanaman sampai tanaman padi berumur 70 hst. Jenis padi Varietas Ciherang $(\mathrm{Ch})$ cenderung memberikan tinggi tanaman yang lebih baik, yaitu 114,93 cm, pada Inpari 10 (I10) dan Inpari 3 memberikan tinggi tanaman, yaitu $112,38 \mathrm{~cm}$ dan 111,35 atau cenderung lebih rendah $2,22 \%$ dan $3,11 \%$ dibandingkan dengan Varietas Ciherang (Ch).

Tabel 1. Pengaruh jenis varietas dan kepadatan tanam terhadap tinggi tanaman dan jumlah anakan pada pengamatan terakhir (56 hst)

\begin{tabular}{lrrrrr}
\multicolumn{1}{c}{ Perlakuan } & $\begin{array}{l}\text { Tinggi } \\
\text { tanaman }\end{array}$ & & \multicolumn{2}{l}{$\begin{array}{l}\text { Jumlah } \\
\text { anakan per } \mathrm{m}^{2}\end{array}$} \\
\hline Jenis varietas padi & 101.91 & $\mathrm{a}$ & 346.15 & $\mathrm{a}$ \\
\hline Ch (Ciherang) & 94.85 & $\mathrm{a}$ & 366.48 & $\mathrm{a}$ \\
\hline I3 (Inpari 3) & 98.92 & $\mathrm{a}$ & 387.04 & $\mathrm{a}$ \\
\hline I10 (Inpari 10) & - & & & - & \\
\hline BNT 5\% & & & & \\
\hline Populasi legowo 2:1 & 98.24 & $\mathrm{a}$ & 353.47 & $\mathrm{bc}$ \\
\hline To (tegel 250.000/ha & 99.24 & $\mathrm{a}$ & 331.22 & $\mathrm{c}$ \\
\hline Lk (legowo 166.666/ha) & 97.80 & $\mathrm{a}$ & 368.06 & $\mathrm{bc}$ \\
\hline Lo (legowo 250.000/ha) & 98.97 & $\mathrm{a}$ & 413.48 & $\mathrm{a}$ \\
\hline Lp (legowo 333.333/ha) & - & & 52.52 & \\
\hline BNT 5\% & & & & & \\
\hline Angkangka yang dikk
\end{tabular}

Keterangan : Angka-angka yang diikuti oleh huruf yang sama pada perlakuan dan kolom yang sama berarti berbeda tidak nyata pada uji BNT 5\%

Tanam jajar legowo 2:1 dengan kepadatan 333.333 rumpun per hektar (Lp) cenderung memberikan tinggi tanaman yang lebih baik, yaitu $115,17 \mathrm{~cm}$, atau cenderung lebih tinggi $2.69 \%$ bila dibandingkan dengan tinggi tanaman yang dicapai pada kepadatan 250.000 rumpun per hektar dengan cara tanam tegel (To) (Tabel 1).

\section{Jumlah anakan}

Pengaruh jenis varietas padi terhadap perkembangan jumlah anakan per meter persegi mencapai maksimum pada padi berumur 35 hst. Jenis padi Varietas Ciherang $(\mathrm{Ch})$ cenderung memberikan jumlah anakan per meter persegi pada umur 35 hst lebih banyak, yaitu 696,15 batang. Pada Varietas Inpari 10 (I10) dan Inpari 3 (I3) memberikan jumlah anakan maksimum umur 35 hst, yaitu 683,48 batang atau cenderung lebih sedikit 1,82\% dan 16,79\% dibandingkan dengan Varietas Ciherang $(\mathrm{Ch})$.Pengaruh jenis varietas padi terhadap perkembangan jumlah anakan per meter persegi makin menurun setelah pengamatan umur 35 hst sampai terendah pada padi berumur 56 hst. Jenis padi Varietas Inpari 10 (Vh) memberikan jumlah anakan per meter persegi pada umur 56 hst lebih banyak, yaitu 350,74 batang, atau secara nyata lebih banyak 
9,82\% dibandingkan dengan Varietas Ciherang (Ch) (Tabel 1).

Pengaruh kepadatan tanam pada tanam jajar legowo 2:1 terhadap perkembangan jumlah anakan per meter persegi padi menunjukkan pertambahan maksimum pada padi berumur $35 \mathrm{hst}$. Tanam jajar legowo 2:1 dengan populasi 333.333 rumpun per hektar (Lp) pada umur 35 hst memberikan jumlah anakan per meter persegi yang lebih banyak, yaitu 909,83 batang, atau nyata lebih banyak $33,68 \%$ dibandingkan dengan jumlah anakan per meter persegi yang dicapai pada populasi 250.000 rumpun per hektar tanam tegel (To). Tanam jajar legowo 2:1 dengan populasi 333.333 rumpun per hektar (Lp) pada umur 56 hst memberikan jumlah anakan per meter persegi yang lebih banyak, yaitu 398,21 batang, atau nyata lebih banyak $25,34 \%$ dibandingkan dengan jumlah anakan per meter persegi yang dicapai pada populasi 250.000 rumpun per hektar tanam tegel (To) (Tabel 1).

\section{Jumlah anakan produktif}

Pengaruh jenis varietas padi menunjukkan bahwa Varietas Inpari 10 (I10) cenderung memberikan jumlah anakan produktif per rumpun lebih banyak, yaitu 15,44 batang dan Inpari 3 (I3), yaitu 14,17 batang, atau cenderung lebih banyak $20,53 \%$ dan 10,62\% dibandingkan dengan Varietas Ciherang (Ch) (Tabel 4). Pengaruh jenis varietas padi terhadap jumlah anakan produktif per meter persegi lebih banyak yaitu pada Varietas Inpari 10 (I10) dan Inpari 3 (I3), yaitu 385,94 batang dan 339,79 batang secara nyata memberikan jumlah anakan produktif per meter persegi lebih banyak $25,44 \%$ dan $10,53 \%$ dibandingkan dengan Varietas Ciherang (Ch) (Tabel 2).

Pengaruh kepadatan tanam pada tanam terhadap perkembangan jumlah anakan produktif per rumpun padi menunjukkan bahwa tanam jajar legowo 2:1 dengan kepadatan 166.666 rumpun per hektar (Lk) berbeda nyata memberikan jumlah anakan produktif per rumpun yang lebih banyak, yaitu 17,98 batang, atau lebih banyak $36,63 \%$ dibandingkan dengan jumlah anakan produktif per rumpun yang dicapai pada kepadatan 250.000 rumpun per hektar tanam tegel (To). Tanam jajar legowo 2:1 dengan kepadatan 333.333 rumpun per hektar (Lp) nyata memberikan jumlah anakan produktif per meter persegi yang lebih banyak, yaitu 395,52 batang, dan 352,78 batang pada Lo atau nyata lebih banyak $21,18 \%$ dan $7,36 \%$ dibandingkan dengan jumlah anakan produktif per meter persegi yang dicapai pada kepadatan 250.000 rumpun per hektar tanam tegel (To) (Tabel 2).

\section{Berat kering oven vegetatif per meter persegi}

Pengaruh jenis varietas padi menunjukkan bahwa Varietas Ciherang (Ch) cenderung memberikan berat kering oven vegetatif per meter persegi lebih berat, yaitu 594,42 g. Pada Inpari 10 (I10) dan Inpari 3 (I3), memberikan berat kering oven vegetatif, yaitu 528,42 g dan 532.44 $\mathrm{g}$, atau cenderung lebih ringan $11,13 \%$ dan $10,43 \%$ dibandingkan dengan Varietas Ciherang (Ch).

Tanam jajar legowo 2:1 dengan kepadatan 333.333 rumpun per hektar (Lp) nyata memberikan berat kering oven vegetatif per meter persegi yang lebih berat, yaitu $664,07 \mathrm{~g}$, atau nyata lebih berat $42,51 \%$ dibandingkan dengan berat kering oven vegetatif per meter persegi yang dicapai pada kepadatan 250.000 rumpun per hektar tanam tegel (To) (Tabel 2).

\section{Persentase gabah berisi}

Jenis varietas padi berpengaruh tidak nyata terhadap persentase gabah berisi. Pengaruh jenis varietas padi menunjukkan bahwa Varietas Inpari 3(I3) cenderung memberikan persentase gabah berisi lebih baik, yaitu 87,26\%. Pada Inpari 10 (I10) dan Ciherang (Ch), memberikan persentase gabah berisi, yaitu $82,32 \%$ dan $83.15 \%$ (Tabel 3). 
Tanam jajar legowo 2:1 dengan kepadatan 250.000 rumpun per hektar (Lo) memberikan persentase gabah berisi yang lebih baik, yaitu 85,08\% (Tabel 3).

Tabel 2. Pengaruh jenis varietas dan kepadatan tanam terhadap jumlah anakan produktif per rumpun, jumlah anakan produktif per meter persegi dan berat kering oven vegetatif per meter persegi

\begin{tabular}{|c|c|c|c|}
\hline Perlakuan & $\begin{array}{l}\text { Jumlah anakan } \\
\text { produktif per } \\
\text { rumpun } \\
\text { (bt) }\end{array}$ & $\begin{array}{l}\text { Jumlah anakan } \\
\text { produktif per } \\
\text { meter persegi } \\
\text { (bt) }\end{array}$ & $\begin{array}{l}\text { Berat kering oven } \\
\text { vege tatif per me } \\
\text { ter persegi }(\mathrm{g})\end{array}$ \\
\hline \multicolumn{4}{|l|}{ Jenis varietas padi } \\
\hline Ch (Ciherang) & 12.81 & 307.42 & $594.42 \quad \mathrm{a}$ \\
\hline I3 (Inpari 3) & $14.17 \mathrm{ab}$ & $339.79 \quad \mathrm{Ab}$ & 532.44 \\
\hline I10 (Inpari 10) & $15.44 \mathrm{a}$ & $385.64 \mathrm{~A}$ & 528.27 \\
\hline BNT 5\% & 2.62 & 54.94 & 196.99 \\
\hline \multicolumn{4}{|l|}{ Kepadatan legowo 2:1 } \\
\hline To (tegel $250.000 / \mathrm{ha}$ & 13.14 & 328.61 & 465.99 \\
\hline $\begin{array}{l}\text { Lk (legowo } \\
166.666 / \mathrm{ha})\end{array}$ & 17.98 & 300.23 & 445.60 \\
\hline $\begin{array}{l}\text { Lo (legowo } \\
250.000 / \mathrm{ha})\end{array}$ & $13.57 \mathrm{~b}$ & $352.78 \mathrm{Ab}$ & $631.18 \quad \mathrm{ab}$ \\
\hline Lp (legowo 333.333/ha) & $11.88 \mathrm{~b}$ & $395.52 \mathrm{~A}$ & $664.07 \quad \mathrm{a}$ \\
\hline BNT $5 \%$ & 2.09 & 46.12 & 179.75 \\
\hline
\end{tabular}

Keterangan : Angka-angka yang diikuti oleh huruf yang sama pada perlakuan dan kolom yang sama berarti berbeda tidak nyata pada uji BNT 5\%

Tabel 3. Pengaruh jenis varietas dan kepadatan tanam terhadap persentase gabah berisi, berat kering oven 1000 butir gabah dan berat kering panen gabah per meter persegi

\begin{tabular}{|c|c|c|c|}
\hline Perlakuan & $\begin{array}{c}\text { Perentase } \\
\text { gabah berisi } \\
(\%)\end{array}$ & $\begin{array}{l}\text { Berat kering } \\
\text { oven } 1000 \text { butir } \\
\text { gabah }(\mathrm{g})\end{array}$ & $\begin{array}{l}\text { Berat kering panen } \\
\text { gabah per meter } \\
\text { persegi }(\mathrm{g})\end{array}$ \\
\hline \multicolumn{4}{|l|}{ Jenis varietas padi } \\
\hline Ch (Ciherang) & 83.15 & 24.42 & 920.04 \\
\hline I3 (Inpari 3) & 87.26 & 26.75 & 859.58 \\
\hline I10 (Inpari 10) & 82.32 & 25.68 & 989.46 \\
\hline BNT 5\% & 6.35 & 1.04 & 182.16 \\
\hline \multicolumn{4}{|l|}{ Kepadatan legowo 2:1 } \\
\hline To (tegel $250.000 / \mathrm{ha}$ & 84.42 & 25.97 & 924.81 \\
\hline $\begin{array}{l}\text { Lk (legowo } \\
166.666 / \mathrm{ha})\end{array}$ & 83.50 & 25.39 & 640.45 \\
\hline $\begin{array}{l}\text { Lo (legowo } \\
250.000 / \mathrm{ha})\end{array}$ & 85.08 & 25.23 & 955.14 \\
\hline Lp (legowo 333.333/ha) & 83.97 & 25.87 & 1171.72 \\
\hline BNT $5 \%$ & 4.65 & 0.92 & 72.36 \\
\hline
\end{tabular}

Keterangan : Angka-angka yang diikuti oleh huruf yang sama pada perlakuan dan kolom yang sama berarti berbeda tidak nyata pada uji BNT 5\% 
Berat kering oven 1000 butir gabah

Pengaruh jenis varietas padi menunjukkan bahwa Varietas Inpari 10 (I10) dan Inpari 3 (I3) memberikan berat kering oven 1000 butir gabah lebih berat, yaitu $25,68 \mathrm{~g}$ dan $26,75 \mathrm{~g}$, atau lebih berat $5,16 \%$ dan $9,54 \%$ dibandingkan dengan berat kering oven 1000 butir gabah pada Varietas Ciherang (Ch).

Tanam jajar legowo 2:1 dengan kepadatan 333.333 rumpun per hektar (Lp) memberikan berat kering oven 1000 butir gabah, yaitu 25,87 (Tabel 3).

\section{Berat kering panen gabah per meter persegi}

Pengaruh jenis varietas padi menunjukkan bahwa Varietas Inpari 10 (I10) cenderung memberikan berat kering panen gabah per meter persegi lebih berat, yaitu 989,46 g, atau cenderung lebih berat $7,55 \%$ dibandingkan dengan hasil pada Varietas Ciherang (Ch) (Tabel 3).

Tabel 4. Pengaruh jenis varietas dan kepadatan tanam terhadap hasil gabah kering panen per hektar dan hasil gabah kadar air $14 \%$ per hektar

\begin{tabular}{llllll}
\hline Perlakuan & $\begin{array}{c}\text { Hasil gabah } \\
\text { kering panen per } \\
\text { hektar (ton) }\end{array}$ & \multicolumn{2}{c}{$\begin{array}{c}\text { Hasil gabah } \\
\text { kadar air 14\% } \\
\text { per hektar (ton) }\end{array}$} \\
\hline Jenis varietas padi & & & & \\
\hline Ch (Ciherang) & 7.76 & $\mathrm{a}$ & 6.81 & $\mathrm{a}$ \\
\hline I3 (Inpari 3) & 7.28 & $\mathrm{a}$ & 6.39 & $\mathrm{a}$ \\
\hline I10 (Inpari 10) & 7.02 & $\mathrm{a}$ & 6.16 & $\mathrm{a}$ \\
\hline \multicolumn{1}{c}{ BNT 5\% } & 1.44 & & 1.26 & \\
\hline Kepadatan legowo 2:1 & & & & \\
\hline To (tegel 250.000/ha & 7.55 & $\mathrm{ab}$ & 6.63 & $\mathrm{ab}$ \\
\hline Lk (legowo 166.666/ha) & 6.64 & $\mathrm{~b}$ & 5.83 & $\mathrm{~b}$ \\
\hline Lo (legowo 250.000/ha) & 7.12 & $\mathrm{~b}$ & 6.25 & $\mathrm{~b}$ \\
\hline Lp (legowo 333.333/ha) & 8.10 & $\mathrm{a}$ & 7.11 & $\mathrm{a}$ \\
\hline \multicolumn{1}{c}{ BNT 5\% } & 0.95 & & 0.84 & \\
\hline
\end{tabular}

Keterangan: Angka-angka yang diikuti oleh huruf yang sama pada perlakuan dan kolom

Tanam jajar legowo 2:1 dengan kepadatan 333.333 rumpun per hektar (Lp) nyata memberikan hasil kering panen gabah per hektar yang lebih berat, yaitu 8,10 ton, atau nyata lebih berat $7,28 \%$ dibandingkan dengan hasil kering panen
Tanam jajar legowo 2:1 dengan kepadatan 333.333 rumpun per hektar (Lp) nyata memberikan berat kering panen gabah per meter persegi yang lebih berat, yaitu $1171,72 \mathrm{~g}$, atau nyata lebih berat $26,70 \%$ dibandingkan dengan berat kering panen gabah per meter persegi yang dicapai pada kepadatan 250.000 rumpun per hektar tanam tegel (To) (Tabel 3).

\section{Hasil gabah kering panen per hektar}

Pengaruh jenis varietas padi menunjukkan bahwa Varietas Ciherang (Ch) cenderung memberikan hasil kering panen gabah per hektar lebih berat, yaitu 7,78 ton. Pada varietas Inpari 10 (I10) dan Inpari 3 (I3) memberikan hasil kering panen gabah per hektar, yaitu 7,02 ton dan 7,28 ton atau lebih rendah $9,54 \%$ dan $6,19 \%$ dibandingkan dengan hasil pada Varietas Ciherang (Ch) (Tabel 4).

\section{yang sama berarti berbeda tidak nyata pada uji BNT 5\%}

gabah per hektar yang dicapai pada kepadatan 250.000 rumpun per hektar tanam tegel (To) (Tabel 4). 
Hasil gabah kadar air 14\% per hektar

Pengaruh jenis varietas padi menunjukkan bahwa Varietas Ciherang (Ch) cenderung memberikan hasil gabah kadar air $14 \%$ per hektar lebih berat, yaitu 6,81 ton. Pada varietas Inpari 10 (I10) dan
Inpari 3 (I3) memberikan hasil gabah kadar air $14 \%$ per hektar, yaitu 6,16 ton dan 6,17 ton atau lebih rendah 9,54\% dan $6,17 \%$ dibandingkan dengan hasil pada Varietas Ciherang (Ch) (Tabel 4. Gambar $1)$.

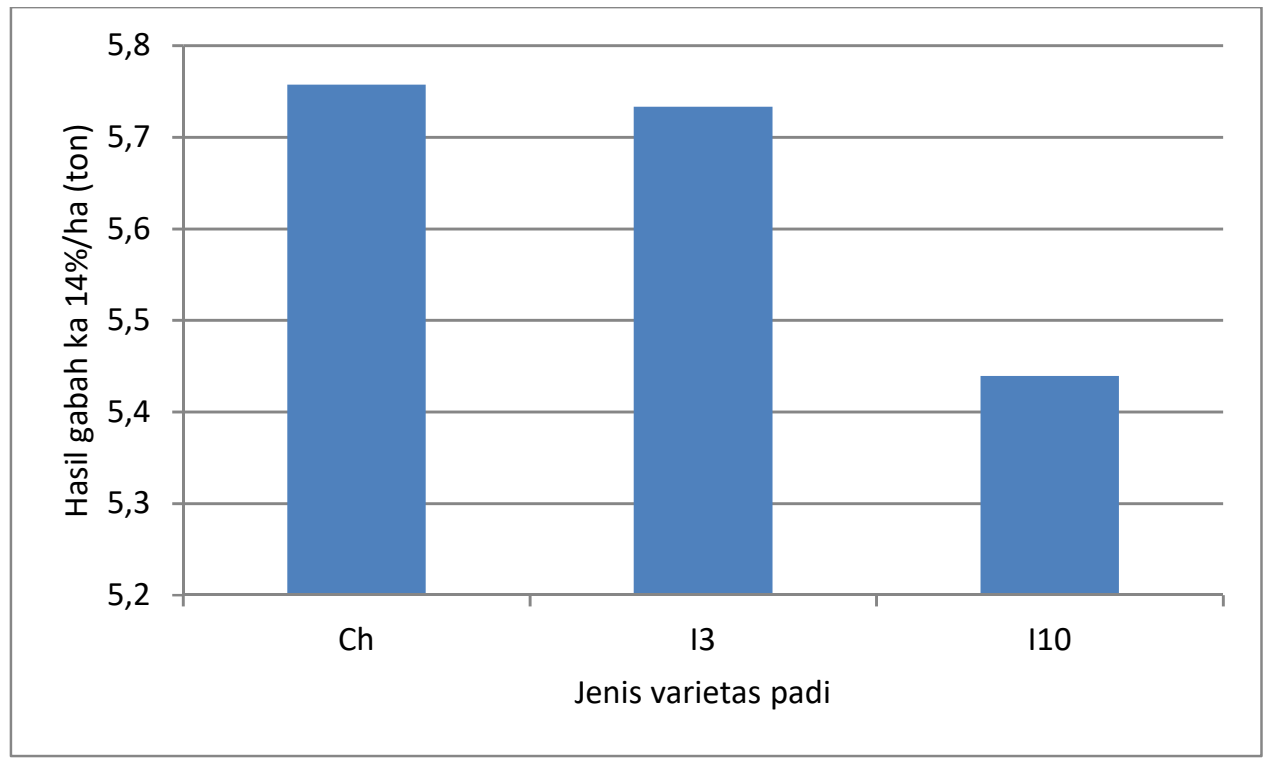

Gambar 1. Hubungan antara jenis varietas dengan hasil gabah kadar air $14 \%$

Tanam jajar legowo 2:1 dengan kepadatan 333.333 rumpun per hektar (Lp) nyata memberikan hasil gabah kadar air $14 \%$ per hektar yang lebih berat, yaitu 7,11 ton, atau nyata lebih berat $7,24 \%$ dibandingkan dengan hasil gabah kadar air $14 \%$ per hektar yang dicapai pada kepadatan 250.000 rumpun per hektar tanam tegel (To) (Tabel 6, Gambar 2).

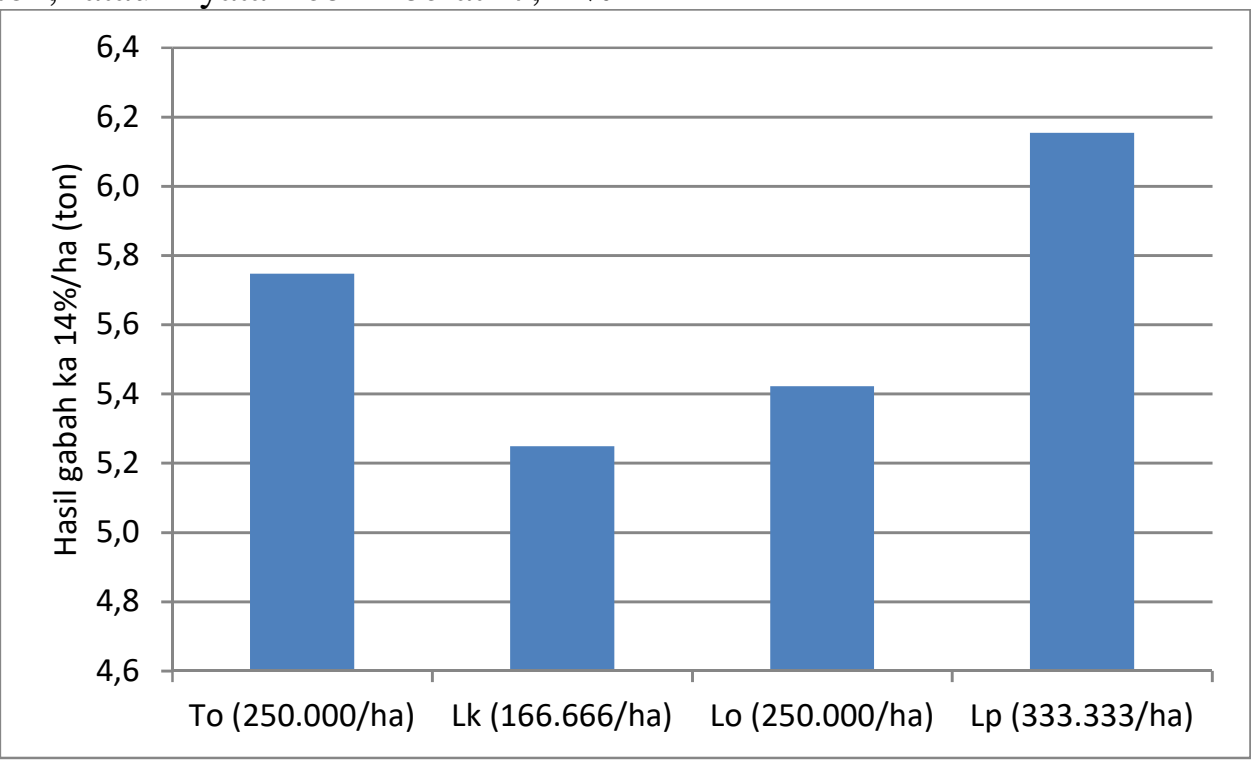

Gambar 2. Hubungan antara kepadatan dengan hasil gabah kadar air $14 \%$ 
Pembahasan

Pengaruh jenis varietas padi

Jenis varietas padi terhadap pertumbuhan tinggi tanaman padi menunjukkan pengaruh yang tidak nyata. Hal ini dapat terjadi karena bahwa diantara varietas padi yang digunakan masih samasama inpari yang belum menujukkan perbedaan meskipun yang secara genetis sudah berbeda, tetapi pada lingkungan ini belum menunjukkan perbedaan tinggi tanaman, disamping itu bahwa dalam diskripsinya dari ketiga varietas yang digunakan tidak ditunjukkan data tinggi tanaman. Selanjutnya bahwa jumlah anakan per meter persegi juga pengaruhnya tidak nyata. Namun ada kecenderungan bahwa padi Varietas Ciherang (Ch) memberikan jumlah anakan per meter persegi pada umur 35 hst lebih banyak, daripada Varietas Inpari 10 (I10) dan Inpari 3 (I3)

Pengaruh jenis Varietas Inpari 10 (I10) dan Inpari 3 (I3) memberikan jumlah anakan produktif per rumpun dan per meter persegi lebih banyak daripada Varietas Ciherang (Ch). Adanya pengaruh yang nyata ini memberikan kemungkinan dari Inpari 10 dan Inpari 3 untuk memberikan hasil yang lebih tinggi daripada Ciherang walaupun Ciherang sudah beradaptasi lama. Secara genetis bahwa Inpari 10 dan Inpari 3 dalam membentuk anakan tidak jauh berbeda dengan Ciherang, mungkin kalau Inpari 10 dan Inpari 3 dikembangkan, akan lebih mampu beradaptasi dilingkungan ini.

Pengaruh jenis varietas padi terhadap berat kering oven vegetatif per meter persegi menunjukkan bahwa Varietas Ciherang (Ch) cenderung lebih baik daripada Inpari 10 (I10) dan Inpari 3 (I3). Hal ini dapat disebabkan karena Varietas Ciherang sudah lama dibudidayakan mungkin sudah lebih dari 15 tahun. Varietas yang terlalu lama digunakan secara terus menerus dapat dengan mudah mengalami serangan oleh hama maupun penyakit. Penyakit yang sering menyerangnya adalah blast, tungro dan atau hama penggerek, sehingga kemungkinan gagal panen cukup mengkhawatirkan, perlu ada pergantian jenis varietas baru dan perlu terus diuji adaptasinya dalam lingkungan ini.

Pengaruh jenis varietas paditerhadap persentase gabah berisi berbeda tidak nyata dancenderung yang baik ditunjukkan oleh Varietas Inpari 3 (I3). Demikian juga pengaruh jenis varietas padi terhadap berat kering panen gabah per meter persegi berbeda tidak nyata dan Varietas Inpari 10 (I10) cenderung memberikan berat kering panen gabah per meter persegi lebih baik dibandingkan dengan hasil pada Varietas Ciherang (Ch). Melihat kecenderungankecenderungan ini yang tidak konsisten berarti bahwa dari ketiga varietas yang telah dicoba ini yang manapun akan dipilih akan memberikan hasil yang serupa hanya saja varietas baru masih perlu uji adaptasi.

Walaupun demikian bahwa Varietas Ciherang (Ch) cenderung memberikan hasil kering panen gabah per hektar lebih berat. Pada Varietas Ciherang (Ch) cenderung memberikan hasil gabah kadar air $14 \%$ per hektar juga lebih baik, yaitu 6,81 ton. Selanjutnya pada varietas Inpari 10 (I10) dan Inpari 3 (I3) memberikan hasil gabah kadar air 14\% per hektar, yaitu 6,16 ton dan 6,17 ton atau lebih rendah $9,54 \%$ dan $6,17 \%$ dibandingkan dengan hasil pada Varietas Ciherang (Ch). Ini berari bahwa Ciherang masih unggul dari segi hasil dan secara potensial bahwa Varietas Ciherang dapat memberikan hasil 8,5 t/ha, sedangkan Varietas Inpari 3 dan Inpari 10 yaitu mencapai 7,52 ton/ha, dan 7,00 t/ha pada kadar air 14\% ( Suprihatni, 2011)

\section{Pengaruh kepadatan tanam}

Pengaruh kepadatan tanam terhadap tinggi tanaman umur 70 hst menunjukkan bahwa tanam jajar legowo 2:1 dengan kepadatan 333.333 rumpun per hektar (Lp) cenderung memberikan tinggi tanaman yang lebih baik. Kecenderungan yang tinggi ini kemungkinan dapat disebabkan oleh populasi yang paling rapat dari 
perlakuan kepadatan lainnya yang lebih rendah. Mungkin ada persaingan terhadap cahaya matahari dan ruang tumbuh sehingga ada sedikit rangsangan untuk tumbuh lebih tinggi, walaupun belum sampai nyata tetapi bisa mempengaruhi variabel lain yang mendukung untuk memberikan hasil yang lebih berbeda.

Hal ini tampak pengaruhnya pada variebel jumlah anakan bahwa tanam jajar legowo 2:1 dengan kepadatan 333.333 rumpun per hektar (Lp) pada umur $35 \mathrm{hst}$ memberikan jumlah anakan per meter persegi yang lebih banyak. Sebaliknya Pengaruh kepadatan tanam pada cara tanam jajar legowo 2:1 terhadap perkembangan jumlah anakan produktif per rumpun padi menunjukkan, bahwa tanam jajar legowo 2:1 dengan kepadatan 166.666 rumpun per hektar (Lk) berbeda nyata dan memberikan jumlah anakan produktif per rumpun yang lebih banyak. Berpengaruhnya kepadatan tanam pada cara tanam legowo baik pada jumlah anakan produktif per rumpun dan per hektar dapat disebabkan oleh ruang gerak yang belum kompetitif, sehingga dengan kepadatan tanam yang rapat pun masih mampu memberikan jumlah anakan per meter persegi yang lebih banyak. Ini berarti masih perlu jarak tanamnya dirapatkan lagi. Pada kepadatan yang sama menunjukkan bahwa cara legowo berbeda tidak nyata dengan cara tegel terhadap jumlah anakan per meter persegi. Jadi bukannya cara tanam legowo memberikan pengaruh yang lebih baik daripada cara tanam tegel, tetapi hanya karena perbedaan jumlah kepadatan tanam yang memberikan perbedaan yang nyata, dengan kepadatan tanam yang lebih banyaklah yang memberikan pengaruh yang lebih baik. Kenyataan ini menunjkan bahwa kesuburan tanah cukup rendah sehingga jarak tanam yang rapat memberikan hasil per meter persegi yang lebih tinggi dari pada jarak tanam yang luas.

Hal ini jelas sekali tampak pada hail percobaan ini bahwa tanam jajar legowo
2:1 dengan kepadatan 333.333 rumpun per hektar (Lp) nyata memberikan berat kering oven vegetatif per meter persegi yang paling berat. Berpengaruhnya tanam jajar legowo 2:1 dengan kepadatan 333.333 rumpun per hektar (Lp) erat kaitannya dengan pengamatannya terhadap berat kering panen gabah per meter persegi. Tanam jajar legowo 2:1 dengan kepadatan 333.333 rumpun per hektar (Lp) nyata memberikan berat kering panen gabah per meter persegi yang lebih berat, bila dibandingkan dengan pada penggunaan kepadatan tanam yang lebih sedikit dan cara tegel. Cara tanam legowo pada kepadatan 250.000 rumpun per hektar sama pengaruhnya dengan cara tegel pada kepadatan yang sama. Hal ini juga terjadi pada variabel hasil kering panen gabah per hektar. Selanjutnya bahwa tanam jajar legowo 2:1 dengan kepadatan 333.333 rumpun per hektar (Lp) nyata memberikan hasil gabah kadar air 14\% per hektar yang lebih berat, yaitu 7,11 ton, atau nyata lebih berat $7,24 \%$ dibandingkan dengan hasil gabah kadar air $14 \%$ per hektar yang dicapai pada kepadatan 250.000 rumpun per hektar pada cara tanam legowo (Lo) dan cara tanam tegel (To).

Hasil dari percobaan ini sesuai dengan kajian pustaka bahwa jarak tanam merupakan masalah praktis di lapangan karena sangat menentukan dalam usaha meningkatkan hasil. Hal ini sejalan dengan hasil penelitiannya Sulistyono dan Rudy (dalam Naya,2010) yang menunjukan bahwa kepadatan tanaman berpengaruh terhadap jumlah anakan dan hasil. Jarak tanam yang lebih besar akan menghasilkan anakan yang lebih banyak, pertumbuhan akar yang lebih baik. Hal itu terjadi karena pembentukan ukuran bioreactornya tanaman semakin leluasa, sedangkan persaingan antar kebutuhan hidup tanaman makin sedikit, baik nutrisi maupun cahaya matahari. Namun, harus diperhatikan juga bahwa semakin jarang jarak tanam akan mempengaruhi jumlah kepadatan persatuan luas, untuk itu pengaturan jarak 
tanam sangat diperlukan. (Purwasasmita dan Sutaryat, 2012)

\section{Pengaruh interaksi antara jenis varietas padi dan kepadatan tanam.}

Pengaruh interaksi antara jenis varietas padi dan kepadatan tanam pada cara tanam jajar legowo 2:1 belum menunjukkan perbedaan yang nyata. Hal ini dapat terjadi oleh beberapa sebab kemungkinan, salah satunya adalah jenis varietas berpengaruh tidak nyata terhadap hasil-hasil padi.

\section{SIMPULAN DAN SARAN \\ Simpulan}

Berdasarkan dari hasil dan pembahasan, maka dapat diambil simpulan sebagai berikut:

1. Jenis varietas padi berpengaruh tidak nyata terhadap hasil gabah kadar air $14 \%$ per hektar. Varietas Ciherang cenderung memberikan hasil gabah kadar air $14 \%$ per hektar lebih berat, yaitu 6,81 ton.

2. Tanam jajar legowo 2:1 dengan kepadatan 333.333 rumpun per hektar nyata memberikan hasil gabah kadar air $14 \%$ per hektar yang lebih berat, yaitu 7,11 ton, atau nyata lebih berat daripada hasil gabah kadar air 14\% per hektar cara taam legowo dan tegel pada kepadatan 250.000 rumpun per hektar.

3. Interaksi antara jenis varietas padi dan kepadatan tanam berpengaruh tidak nyata.

\section{Saran-saran}

Saran-saran yang dapat disampaikan dari hasil percobaan ini adalah agar dicari varietas yang memberikan hasil yang sama atau lebih dari Varietas Ciherang atau dapat menggunakan kepadatan yang lebih rapat.

\section{DAFTAR PUSTAKA}

Anonimimus. 2011a. www.informasipertanian.com /search/label/ Teknologi Pertanian

Anonimimus.2011b. Budidaya Padi Sistem Jajar Legowo. www.gerbangpertanian.com

Anonimimus. 2012. INPARI 3. www.academia.edu

Naya,P. 2010. Pengaruh Jarak Tanam Terhadap Pertumbuhan dan Produksi Beberapa Varietas Unggul Padi Sawah. Skripsi. Tidak dipublikasikan. Universitas Panji Sakti Singaraja.

Purwasasmita, Sutaryat. 2012. Padi SRI Organik Indonesia. Penebar Swadaya. Jakarta

Rubiyo, Suprapto dan A.Darajat. 2005. Evaluasi Beberapa Galur Harapan Padi Sawah di Bali. Balai Pengkajian Teknologi Pertanian.Bali.Balai Penelitian Tanaman Padi Sukamandi.

Sembiring,H. 2008. Kebijakan Penelitian dan Hasil Penelitian Balai Besar Padi dalam mendukung Peningkatan Produksi Beras Nasional. Prosiding SeminarApresiasi Hasil Penelitian. Balai Besar Penelitian Tanaman Pangan.Sukamandi.

Suiatna.R.U. 2010. Bertani Padi Organik Pola Tanam SRI. Padi Bandung. Bandung.

Suprihatni,B.,Aan,A.,Darajat,Satoto,Suwar no,Erwin Lubis, Baehaki,S.E., Sudir, S.D.Indasari,I.P.Wardana,Made Jana Mejana. 2011. Deskripsi Varietas Padi (Edisi Revisi). Balai Besar Penelitian Tanaman Padi. Badan Penelitian dan Pengembangan Pertanian. 